\title{
Miranda
}

Revue pluridisciplinaire du monde anglophone /

Multidisciplinary peer-reviewed journal on the English-

speaking world

1 | 2010

Variations on Darwin

\section{La science et le savoir obscur dans Jude the Obscure de Thomas Hardy}

\section{Stéphanie Bernard}

URL : http://journals.openedition.org/miranda/586

DOI : 10.4000/miranda.586

ISSN : 2108-6559

\section{Éditeur}

Université Toulouse - Jean Jaurès

\section{Référence électronique}

Stéphanie Bernard, «La science et le savoir obscur dans Jude the Obscure de Thomas Hardy », Miranda [En ligne], 1 | 2010, mis en ligne le 23 mars 2010, consulté le 16 février 2021. URL : http:// journals.openedition.org/miranda/586 ; DOI : https://doi.org/10.4000/miranda.586

Ce document a été généré automatiquement le 16 février 2021.

\section{(c) (i) () $\Theta$}

Miranda is licensed under a Creative Commons Attribution-NonCommercial-NoDerivatives 4.0 International License. 


\title{
La science et le savoir obscur dans Jude the Obscure de Thomas Hardy
}

\author{
Stéphanie Bernard
}

1 Le dix-neuvième siècle est celui du roman réaliste, qui tente de réconcilier fiction et réalité, imagination et savoir scientifique. C'est aussi le siècle de la désillusion et de la perte d'autorité de la religion. Thomas Hardy est à cet égard bien ancré dans son temps: auteur prolifique, il fut aussi un grand lecteur, choisissant des œuvres éclectiques. Défenseur d'ouvrages précurseurs tels que The Origin of Species de Darwin, architecte, amateur d'art et d'histoire, fasciné par l'archéologie, il utilise ces ressources pour parfaire la délinéation des mondes qu'il dépeint, mais la science laisse une trace ambiguë dans son œuvre. Ainsi, les découvertes en astronomie lui inspirèrent le récit Two on a Tower; elles renforcèrent sa vision de l'homme comme rien de plus qu'un grain de poussière dans l'univers, « like a fly on a billiard-table of indefinite length, and of no more consequence to the surroundings than the fly" (Hardy 1998, 110). La moissonneuse dans Tess of the D'Urbervilles, le chemin de fer dans Jude the Obscure sont autant d'intrusions mortifères du progrès dû à la science. Hardy s'intéressa également à la philosophie - notamment de Schopenhauer - et la question religieuse. Si ces différentes sources n'ont pas qualité d'écrit scientifique, elles sont néanmoins le fruit des grandes découvertes ou explorations scientifiques de l'époque et porteuses des germes de la modernité. Ce qui importe plus encore, c'est le style de l'auteur qui n'eut de cesse de réécrire ce discours. Quoique l'emblématique ouvrage de Darwin eût sur lui une influence considérable, il est indéniable que les traces du discours de l'évolution se trouvent prises dans les mailles de l'écriture hardyenne, si bien que l'esthétique de la poésie et de la fiction dépasse et transcende l'apport scientifique.

\section{1. Écrire sur le savoir et la science}

2 L'auteur en revient toujours à la petitesse de l'homme, soumis à des lois de sélection naturelle sur lesquelles il n'a pas de prise, dans un univers immense et insaisissable. Une part d'inconnu, un pan d'obscurité habitent les romans, les nouvelles et les poèmes 
de Hardy. Le vertige qui entraîne lecteur et personnages semble conduire à la limite d'un possible, d'un supportable. C'est une faille - terme pris d'abord dans sa dimension géologique - qui met un point d'arrêt à ce vertige, c'est un espace qui va faire cesser la fuite folle de l'imagination d'un côté, du discours scientifique de l'autre. C'est peut-être là qu'opère la disjonction entre savoir obscur et savoir scientifique, entre rêverie et pragmatisme aussi.

deux premiers paragraphes de la nouvelle intitulée The Fiddler of the Reels font allusion à la Grande Exposition de 1851, censée cristalliser le triomphe de l'Empire, de la science et du progrès, que le texte présente comme une véritable ligne de rupture :

" Talking of Exhibitions, World's Fairs, and what not, " said the old gentleman, «I would not go round the corner to see a dozen of them nowadays. The only exhibition that ever made, or ever will make, any impression upon my imagination was the first of the series, the parent of them all, and now a thing of old times - the Great Exhibition of 1851, in Hyde Park, London. None of the younger generation can realize the sense of novelty it produced in us who were then in our prime [...]» For South Wessex, the year formed in many ways an extraordinary chronological frontier or transit-line, at which there occured what one might call a precipice in Time. As in a geological 'fault', we had presented to us a sudden bringing of ancient and modern into absolute contact, such as probably in no other single year since the Conquest was ever witnessed in this part of the country (Hardy 1990, 494)

4 Le contraste dévoile déjà une ambivalence : la faille ("a geological 'fault' ») éloigne autant qu'elle crée du lien entre deux mondes. Elle est à la fois séparation et rapprochement: "an extraordinary chronological frontier or transit-line». On pourrait lire dans cette ligne de rupture de l'Exposition, la métaphore d'une autre ligne de faille plus profonde, comme si la mutation de 1859 s'exprimait par le déplacement et la hantise, conduisant Hardy à décliner le paradigme d'une géométrie du progrès, de sa faille ou faillite. Cette ligne trouvera, nous le verrons, son aboutissement dans la construction géométrique du roman Jude the Obscure ${ }^{1}$ : ce cadre cartésien, aux contours bien tracés et aux angles droits, définit du même coup l'espace dans lequel va déborder ce qui se cache au-delà, hors du texte et de la scène - ce qui est ob-scène, non vérifiable et non calculable.

5 La faille rappelle en outre les voies de chemin de fer qui tantôt permettent aux personnages de se rejoindre, tantôt les éloignent les uns des autres. Symptôme du progrès dans les deux derniers romans de Hardy, le réseau ferré grandissant évoque une nature en voie de mécanisation qui n'offre plus d'alternative à la société. Si Tess évolue d'abord dans un univers à peine industrialisé - «for the railways which engirdled this interior tract of country had never yet struck across it » (Hardy 1998, 107) -, elle perçoit peu à peu le rideau de fer que la révolution industrielle dresse autour de certaines parties du Wessex. La survie du lieu semble compromise par les forces de la modernité, comme si le lieu lieu-même était soumis à un processus de mutation et de sélection.

6 Le monde de Hardy, raturé par la ligne de la science et du progrès, se minéralise. Le quadrillage des exploitations agricoles dans Tess of the D'Urbervilles anticipe le maillage du complexe ferroviaire de Jude ainsi que les pierres anguleuses des bâtiments de Christminster. Et si les théories de Darwin ont profondément marqué la peinture de la destinée des personnages, comme nous le verrons, le corollaire inattendu de cette porosité du discours scientifique, c'est précisément son envers, puisque le savoir se fait inaccessible et que le lieu de science par excellence, l'université, s'évide et se refuse au 
protagoniste. Ce que Jude, amoureux de ces nobles constructions qu'il juge dignes de la Jérusalem céleste (Hardy 1996, 18), retient de la ville universitaire, ce sont les recoins obscurs et les sculptures enchevêtrées :

When the gates were shut, and he could no longer get into the quadrangles, he rambled under the walls and doorways, feeling with his fingers the contours of their mouldings and carvings. The minutes passed, fewer and fewer people were visible, and still he serpentined among the shadows [...] High against the black sky the flash of a lamp would show crocketed pinnacles and indented battlements. Down obscure alleys, apparently never trodden now by the foot of man, and whose very existence seemed to be forgotten, there would jut into the path porticoes, oriels, doorways of enriched and florid middle-aged design, their extinct air being accentuated by the rottenness of the stones. (Hardy 1996, 94)

Christminster révèle à la nuit tombante sa face cachée. Ce lieu semble tout à coup inconnu et abandonné. Tout y est en excès : les gravures, les lignes serpentines, les ornements. Ce travail de la pierre affleure soudain lorsque les érudits, ceux qui savent et ordonnent, ont quitté cet endroit. La vision idéalisante de Jude, son regard d'enfant aussi peut-être, donnent vie à une réalité insoupçonnée, à un univers quasi-fantastique, comme s'il passait de l'autre côté du miroir.

8 Ce regard capable de revêtir de vie et de lumière l'insaisissable et dure réalité de Christminster est déjà à l'œuvre dans les premières pages du roman, lorsque le jeune Jude, perché sur une échelle et à des kilomètres de la ville, tente d'en percevoir les contours :

Some way within the limits of the stretch of landscape, points of light like the topaz gleamed. The air increased in transparency with the lapse of minutes, till the topaz points showed themselves to be vanes, windows, wet roof slates, and other shining spots upon the spires, domes, freestone-work, and varied outlines that were faintly revealed. It was Christminster, unquestionably ; either directly seen, or miraged in the peculiar atmosphere. (Hardy 1996, 19)

9 La vision autorise chez Jude l'illusion. Elle nourrit sa quête incessante de Sue et de l'accomplissement d'un savoir académique. Elle le conduit à suivre les chemins du Wessex, de Christminster à Melchester, de Shaston à Aldbrickham - autant de noms sortis de l'imaginaire de l'auteur.

10 Plus tard, alors que les ambitions du jeune homme ont été anéanties et qu'il erre dans la ville universitaire, il se retrouve dans un endroit dont la forme, métonymie métatextuelle, semble illustrer la stricte géométrie du récit : « an octagonal chamber in the lantern of a singularly built theatre » (139). Cet espace symbolise l'enfermement du protagoniste à la fois dans son impossible rêve et dans le carcan social de son époque. C'est d'ailleurs là qu'il se souviendra, des années plus tard, de ses illusions perdues :

[...] there arose on Jude's sight the circular theatre with that well-known lantern above it, which stood in his mind as the sad symbol of his abandoned hopes [...] (386)

11 Du savoir scientifique délivré derrière les murs des universités, il ne saura rien. Il n’y a pas accès :

Those buildings and their associations and privileges were not for him. From the looming roof of the great library, into which he hardly ever had time to enter, his gaze travelled on to the varied spires, halls, gables, streets, chapels, gardens, quadrangles, which composed the ensemble of this unrivalled panorama. (139)

D'un côté l'ordre et les lignes de faille - les portes, les murs, les rues - qui le séparent de son rêve. De l'autre, la vision qui dévoile aux yeux de Jude les courbes cachées, les 
bosses et les creux qu'ignorent ceux qui détiennent l'assurance du savoir et de la bienséance.

Les professeurs de Christminster - double fictionnel d'Oxford - n'ont que du dédain pour ceux qui, comme Jude, voudraient rejoindre leurs rangs malgré leur appartenance à une classe inférieure. Ils se font ainsi les avocats du déterminisme social inspiré de Darwin et qui fera plier le désir du protagoniste.

He saw that his destiny lay not with these, but among the manual toilers in the shabby purlieu which he himself occupied, unrecognized as part of the city at all by its visitors and panegyrists, yet without whose denizens the hard readers could not read nor the high thinkers think. (139)

14 Jude a retenu la leçon du darwinisme, observant la sélection sociale et la domination des plus forts, dont les polyptotes (« readers/» « read», «thinkers» «think») démontent avec ironie les rouages. C'est le signe de la lucidité du personnage qui, quoique obscur par son existence et sa naissance, illumine le texte par la force de sa vision et de son regard.

Le roman conduit donc le lecteur dans l'exploration de la complexité humaine, vers la découverte du cœur ténébreux des hommes. C'est pourquoi l'empreinte du Darwinisme ne se perçoit pas au travers de récits naturalistes qui seraient inspirés du savoir scientifique sur l'homme et la biologie, de Lyell à Darwin. Elle est avant tout visible dans les destins tragiques de personnages dont les existences sont déterminées par les vies de leurs aïeux : les ancêtres déchus de Tess, les parents malheureux de Jude.

\section{Savoir et désespoir}

Profondément empreinte de la pensée de l'évolution, l'œuvre de Hardy cherche aussi à se dégager du discours scientifique en stigmatisant, de façon implicite ou explicite, le rôle de la science. La notion de progrès est d'emblée problématique, rimant moins avec bonheur qu'avec erreur - « fault » pour reprendre le terme de la nouvelle The Fiddler of the Reels. Les avancées de la science n'offrent nul réconfort au genre humain dans l'univers hardien.

17 Le personnage de Sue, si discutée pour ses positionnements contradictoires, est peutêtre plus proche ici du point de vue de Hardy qu'on ne le pense généralement. Pourtant, à l'époque de la publication du roman, Sue semblait placée du côté du progrès, de façon presque univoque. Au contraire de Jude, elle n'aime ni les églises, ni l'art gothique, et ne perçoit rien d'admirable dans les ruines des monuments anciens : « Not ruins, Jude - I don't care for them. [...] and I hate Gothic! » (Hardy 1996, 162). Elle préfère les gares qui sont une véritable fenêtre sur la vie: «[...] I'd rather sit in the railway station [...]. That's the centre of the town life now. The Cathedral has had its way! (160). Sue est une figure des temps modernes, une femme libérée prête à partager la vie d'un homme sans passer par le mariage, emblème du féminisme si l'on en croit un critique de l'époque que Hardy mentionne dans sa Préface :

After the issue of Jude the Obscure as a serial story in Germany, an experienced reviewer of that country informed the writer that Sue Bridehead, the heroine, was the first delineation in fiction of the woman who was coming into notice in her thousands every year - the woman of the feminist movement [...]. (Hardy 1996, ix) modernité, l'avenir ne lui appartient pas. Son refus des traditions la fige dans un 
présent sans perspectives. Elle se définit comme une négation de la civilisation (176) et ajoute : "I am not modern, either. I am more ancient than mediaevalism, if you only knew » (160). Son audace et son anti-conformisme la conduisent au désespoir. Elle finit par se réfugier dans un refus du corps et de tout désir.

Le personnage de Sue chemine donc vers une petite mort. La vie sans vie qu'elle choisit de mener en compagnie d'un mari qu'elle ne désire pas lui arrache des larmes, et même un cri. Mais ensuite c'est le silence. Sue se donne sans amour, par devoir, «clenching her teeth» (477), et disparaît du texte. Son existence suit la courbe descendante que décrit le progrès dans le monde selon Hardy.

Le pessimisme de l'auteur et sa méfiance face au progrès semblent faire écho aux travaux d'August Weismann qui mit en relief l'idée de l'évolution comme transmission de traits héréditaires. Hardy laissa le néo-darwinisme et la notion d'hérédité renouveler sa lecture de l'évolutionnisme. La généalogie, la transmission familiale, la descendance sont autant d'obsessions qui façonnent le style et les thèmes de l'auteur, et lui ont inspiré, par exemple, le poème intitulé Heredity:

I am the family face ;

Flesh perishes, I live on,

Projecting trait and trace

Through time to times anon,

And leaping from place to place

Over oblivion.

The years-heired feature that can

In curve and voice and eye

Despise the human span

of durance - that is I;

The eternal thing in man

That heeds no call to die. (CP 434)

21 La première strophe illustre, par les assonances et les répétitions (" trait and trace », "time to times", "place to place »), le poids d'un déterminisme filial inscrit non seulement sur les visages, mais aussi dans la mémoire des mortels ou dans les paysages ancestraux du Wessex, comme la forêt de Chaseborough pour Tess ou la Maison Brune pour Jude.

Le poème suggère donc combien les implications sociales et familiales conditionnent les individus - combien aussi il est ardu de s'en affranchir : plus que la loi du plus fort, c'est la loi du sang qui détermine les individus dans leur être même. Cette notion est d'ailleurs sous-jacente dans les écrits de Darwin, comme le souligne Beer :

One crucial and recurrent metaphor in The Origin is the heraldic record of great families : «all true [biological] classification is genealogical» (404). Succession and inheritance form the "hidden bond» which knits all nature past and present together, just as succession and inheritance organise society and sustain hegemony. (Beer 210)

24 Ainsi, Sue ne peut échapper à son histoire telle qu'elle est définie d'avance par celle de ses ancêtres : leur fin tragique la coupe de son propre désir. Jude, lui, est le fruit d'un amour tourmenté entre amants déchirés. Il porte la marque de cette blessure qui lui interdit l'accès à l'objet de son désir et le fige dans son l'aliénation. Par sa naissance même, il appartient à l'obscurité, sa vie côtoyant inexorablement la mort. C'est ce que suggèrent les paroles de la vieille tante de Jude qui l'élève: «It would ha' been a 
blessing if Goddy-mighty had took thee too, wi' thy mother and father, poor useless boy! » (Hardy 1996, 9).

L'histoire de Jude et de Sue est déjà écrite. Les mariages malheureux de leurs parents respectifs ne peuvent que se répéter au travers de l'existence des protagonistes, le texte devenant une caisse de résonance où l'écho se prolonge. Ainsi, dès les premières pages et grâce encore à la tante du jeune garçon, le lecteur comprend que son personnage s'inscrit dans une lignée singulière :

"The boy is crazy for books, that he is. It runs in our family rather. His cousin Sue is just the same - so I've heard; but I have not seen the child for years, though she was born in this place, within these four walls, as it happened. My niece and her husband, after they were married, didn't get a house of their own for some years or more ; and then they only had one till - Well, I won't go into that. Jude, my child, don't you ever marry. 'Tisn't for the Fawleys to take that step any more. » (9)

Quelques chapitres plus loin, Arabella, l'épouse très charnelle de Jude, attaque son époux en se servant de cet argument :

«Going to ill-use me on principle, as your father ill-used your mother, and your father's sister [Sue's mother] ill-used her husband? » she asked. « All you be a queer lot as husbands and wives! » (81)

L'écho s'entend encore quelques instants plus tard, toujours par la bouche de la vieille tante :

" It was coming from Alfredstone market, when you were a baby [...] that they had their last difference, and took leave of one another for the last time. Your mother soon afterwards died - she drowned herself, in short, and your father went away with you to South Wessex, and never came here anymore. [...] It was the same with your father's sister. [...] The Fawleys were not made for wedlock $:$ it never seemed to sit well upon us. There's sommat in our blood that won't take kindly to the notion of being bound to do what we do readily enough if not bound. That's why you ought to have harkened to me, and not ha' married. » (J 82)

L'ambiguïté pointe dans ces lignes: la tragédie familiale se répète-t-elle de façon naturelle, génétique, ou bien est-elle portée par une parole - celle de la vieille tante, d'Arabella, et enfin du narrateur? N'est-ce pas aussi par une lettre que Jude comprend que le savoir scientifique et le prestige de la connaissance lui sont interdits?

\section{Langage et désespoir}

Si l'œuvre de Hardy est empreinte d'une pensée darwinienne, c'est parce que la sélection menace toujours les protagonistes d'extinction, mais aussi parce que la culture elle-même est toujours l'affaire du plus fort, et que le capital culturel est toujours refusé au faible, quelles que soient ses aptitudes. On pourrait ainsi considérer que la vision du darwinisme social selon Hardy préfigure les concepts de Bourdieu, comme en témoigne l'unique réponse que Jude reçoit aux missives qu'il a envoyées aux prestigieux professeurs de Christminster :

Sir - I have read your letter with interest; and, judging from your description of yourself as a working-man, I venture to think that you will have a far better chance of success in life by remaining in your own sphere and sticking to your trade than by adopting any other course. That, therefore, is what I advise you to do. Yours faithfully,

T. TETUPHENAY.

« To M. FAWLEY, Stone-mason. » (Hardy 1996, 140) 

Jude, simple ouvrier, n'a droit qu'à un reste du savoir scientifique. De ce contenu académique, analysable et transférable, il ne possède que de vieux livres, écrits en langues mortes, qu'il lit le soir après des heures d'un travail manuel harassant. Si bien qu'avant même d'avoir la réponse du professeur, il connaît la réponse et admet s'être fourvoyé : «the whole scheme had burst up, like an iridescent soap-bubble, under the touch of a reasoned inquiry » (138).

Jude n'a d'autre possibilité que de voler des instants de lectures qui demeurent ensuite dans son esprit telles des voix détachées du réel, tels des lambeaux arrachés aux textes de grands poètes :

[...] he had read and learnt almost all that could be read and learnt by one in his position, of the worthies who had spent their youth within these reverend walls, and whose souls had haunted them in their maturer age. Some of them, by the accidents of his reading, loomed out in his fancy disproportionately large by comparison with the rest. [...] In the gloom it was as if he ran against them without feeling their bodily frames.

The streets were deserted, but on account of these things he could not go in. There were poets abroad [...]. Speculative philosophers drew along [...].

The scientists and philologists followed in his mind-sight [...].

Jude found himself speaking out loud, holding conversations with them [...]. (94-95).

Ces pièces détachées du langage semblent n'être qu'un ensemble de lettres formant des phrases coupées du réel, purs symboles d'une absence. Ils ne désignent rien d'autre que l'imaginaire de Jude amoureux des Belles Lettres. Le savoir que des hommes illustres ont énoncé explose lui aussi comme une bulle de savon au contact de l'interdit dont Jude est l'objet. Ce savoir est mis à distance par le langage qui lui permet autant d'être énoncé qu'il l'amène à être subverti.

Ce jeu entre savoir ou science et langage est également suggéré par les premières lignes de la nouvelle The Fiddler of the Reels où l'emploi du terme "exhibition » en position adjectivale montre à quel point les découvertes, qu'on aurait pu dire géniales, sont finalement banalisées, voire ridiculisées: ironie d'un succès qui rend l'exploit trop connu pour être longtemps honoré.

"A noun substantive went so far as to become an adjective in honour of the occasion. It was » exhibition "hat, " exhibition " razor-strop, " exhibition " watch; nay, even " exhibition " weather, » exhibition " spirits, sweethearts, babies, wives - for the time. » (Hardy 1990, 494)

L'opposition sous-jacente - que trahissent dans la nouvelle les paroles du vieil homme - entre les impressionnantes innovations présentées à l'exposition et l'effet de banalisation opéré par le langage, n'est qu'une autre facette de celle qui peu à peu se fait jour entre l'université telle une tour d'ivoire et la vraie vie de Christminster.

L'érudition se trouve finalement dénoncée comme hors d'atteinte et hors de la réalité. Le premier regard qu'il pose sur les universités conduit Jude à douter de la capacité de ceux qui travaillent derrière ces murs anciens et parfois décrépits à nourrir la pensée moderne: "It seemed impossible that modern thought could house itself in such decrepit and superseded chambers » (Jude 94). La lettre du professeur le pousse un peu plus avant sur le chemin de la désillusion. Errant alors dans la ville, il entrevoit un autre savoir qui s'offre à lui :

He began to see that the town life was a book of humanity infinitely more palpitating, varied, and compendious than the gown life. These struggling men and 
women before him were the reality of Christminster, though they knew little of Christ or Minster. That was one of the humours of things. The floating population of students and teachers, who did know both in a way, were not Christminster in a local sense at all.

He looked at his watch, and, in pursuit of this idea, he went on till he came to a public hall, where a promenade concert was in progress. Jude entered, and found the room full of shop youths and girls, soldiers, apprentices, boys of eleven smoking cigarettes, and light women of the more respectable and amateur class. He had tapped the real Christminster life. (Hardy 1996, 141)

lettre le langage et les symboles du texte. Si le texte obét à la logique de l'évolution sociale, quelque chose se joue dans la puissance d'évocation de l'écriture qui échappe à l'héritage perçu comme mortifère du darwinisme. Ainsi, le lieu où se tient Jude au moment de sa prise de conscience se nomme «The Fourways ». Cette intersection est le centre géométrique de la ville mais également son cœur battant: "It was literally teeming, stratified, with the shades of human groups, who had met there for tragedy, comedy, farce; real enactments of the intensest kind» (141). Le chiffre quatre, première syllabe de ce nom, tend à évoquer la binarité, la symétrie, voire l'enfermement : c'est entre quatre murs (« within these four walls », 9) que débute la vie de Sue marquée par le destin tragique de ses parents ; c'est dans la salle octogonale d'un théâtre de Christminster que Jude comprend son échec. Cependant, avec "Fourways ", l'espace ici délimité s'ouvre en un lieu où s'affirme l'humanité, où les enfants viennent au monde, où les hommes et les femmes s'aiment et se séparent.

At Fourways men had stood and talked of Napoleon, the loss of America, the execution of King Charles, the burning of the Martyrs, the Crusades, the Norman Conquest, possibly of the arrival of Caesar. Here the two sexes had met for loving, hating, coupling, parting; had waited, had suffered, for each other; had triumphed over each other; cursed each other in jealousy ; blessed each other in forgiveness. (141)

Le rythme des verbes réintroduit une dynamique différente dans le texte. L'évocation des déchirements et de la passion de ces couples a quelque chose de l'univers de D. H. Lawrence. Le cœur qui bat ici est celui des hommes : autour de lui la vie s'enroule et se déroule, les émotions se répondent et se répètent indéfiniment. Le déterminisme et autres données scientifiques sont peut-être sous-jacents dans ces lignes, mais c'est avant tout la force du poétique qui est à l'œuvre et façonne le style de l'auteur, fruit d'un savoir obscur sur l'homme inspirant l'écriture.

\section{Le savoir obscur de Jude}

La lettre de Tetuphenay a fonction de déclencheur : elle est le signal du déplacement du désir de Jude. Confronté à l'interdit d'un savoir académique et normatif, Jude va se laisser transporter vers la vie et le corps. Ce savoir obscur lui est d'abord suggéré par Sue qui n'a de cesse, avant que le malheur ne la brise, de critiquer les bien-pensants de 
Christminster et le conformisme social et religieux, elle qui va jusqu'à réécrire, en quelque sorte, le texte biblique, en organisant les livres dans l'ordre chronologique.

N'y a-t-il pas cependant ici quelque chose d'ironique? Tout en dénonçant l'ordre établi, elle se réfugie dans un ordre parallèle, ici chronologique, plus tard mystique, dans tous les cas tendant à nier le corps et ses désirs. Elle est d'ailleurs à demi consciente de ce paradoxe, de cette division qui la traverse. Lorsque Jude lui dit qu'elle est sans doute aussi naïve qu'anti-conformiste ("you are as innocent as you are unconventional!» 178), elle répond: «I am not particularly innocent» (178); la logique voudrait que la phrase se termine par «nor particularly unconventional». Quoique les mots n'apparaissent pas, ils viennent subrepticement à l'esprit du lecteur.

41 Jude, lui, va s'engager sur la voie ouverte par Sue, sans se retourner, sans garde-fou. Lorsqu'il la rencontre, ses lectures des classiques s'espacent et se font moins présentes. Un plus grand nombre de lettres est échangé : la correspondance entre Jude et Sue s'intensifie jusqu'à ce que les amants soient unis l'un à l'autre - hors mariage bien entendu, c'est-à-dire hors la loi, mais au travers du corps. La déchirure qui ensuite désunit ces deux êtres en est d'autant plus douloureuse.

En fait, c'est l'ensemble du roman qui menace de se rompre. Une ligne de rupture le traverse, par le travail de l'écriture qui ponctue le récit du rappel des interdits et en même temps « autorise » que ceux-ci soient enfreints. Comme la faille entre traditions et inventions dans The Fiddler of the Reels, cette ligne sépare et rapproche à la fois. Les personnages longent le précipice, changeant parfois de bord - c'est le cas de Sue, alors que Jude s'y engouffre.

43 Le protagoniste est parfois du côté de l'ordre symbolique, comme dans sa passion pour les Ecritures dont il aime l'enveloppe plutôt que le message, ou encore pour les grands penseurs qui ne comptent pas seulement des poètes mais des scientifiques et des hommes politiques. Son attirance sexuelle pour Sue, qu'il finira par séduire, souligne sa virilité, "the natural man's desire to possess a woman » (422). Mais tout autant que Sue, il connaît la perte (de sa bien-aimée, de ses enfants, de ses ambitions, de son argent et de ses biens). Quoique fautif devant la loi sociale, Jude est victime de sa propre histoire, prédestiné à ne pas être heureux en amour, déterminé en tant qu'homme du peuple. Il est manipulé par Arabella, mais aussi par Sue qui lui avoue qu'elle a d'abord cherché à le séduire par désir d'être désirée (422).

En tout cela, le personnage masculin est féminisé. Se heurtant aux interdits, il est déchu de sa position phallique dominante. Cette position incombe finalement à Arabella, qui parvient à survivre jusqu'au bout en faisant sienne la loi du plus fort. Jude est traversé par la division qui est le lot des femmes ${ }^{2}$. Il est partagé entre ses doctrines et son amour passionné pour Sue, entre son devoir social et ses idéaux, divisé par le symbolique qui lui interdit de vivre corps et âme dans l'imaginaire.

Jude est un être dépossédé, "[d]eprived of the objects of both intellect and emotion " (143). Privé de l'amour de Sue et de son rêve d'érudition, pris dans les mailles du darwinisme social comme si les mots du professeur fonctionnaient de manière performative, il contourne la loi en accédant à la voix du poète lorsqu'il accepte de perdre l'objet de son désir. C'est la demande sans réponse, la coupure entre lui et l'objet qui fondent sa parole ultime dans le texte et permettent au roman de ne pas sombrer lorsque Jude disparaît. 


\section{L'agitat}

Si aux yeux de la science Jude meurt à la fin, le texte laisse entendre que quelque chose continue de se dire, au-delà du leurre de l'absence. Sa beauté n'irradie-t-elle pas lorsque Mrs Edlin et Arabella contemplent le visage du défunt dans les dernières pages du roman? "How beautiful he is! » s'écrie la vieille dame (488). Jude semble bien être vaincu par la faille, tombé au fond du gouffre, mais il demeure cependant dans le texte en tant que sujet spectral. Il passe du côté du "pas-tout", du côté du poétique non vérifiable et ascientifique, du côté du féminin opposé à l'ordre phallique.

Ce retournement du texte se perçoit dans le dernier chapitre décrivant ses derniers instants. Les répétitions qui s'y opèrent - retour à Christminster et son théâtre, à la cérémonie estivale de "Remembrance Day ", à Arabella, aux livres poussiéreux (488-489) - sont des reflets en demi-teinte de la diégèse sur le point de se clore. Plusieurs images dans la narration suggèrent l'effondrement de l'organisation géométrique qui semblait structurer le texte et dessinent les contours d'une ligne serpentine. Par cet effet du poétique, les gestes d'Arabella sont même revêtus d'une certaine grâce, alors même que l'ironie souligne son narcissisme :

It was the afternoon, and Arabella was at the looking-glass curling her hair, which operation she performed by heating an umbrella-stray in the flame of a candle she had lighted, and using it upon the flowing lock. (482)

Le bruit des festivités en l'honneur de «Remembrance Day » vient tournoyer dans la pièce où Jude vit ses derniers instants :

Certain sounds from without revealed that the town was in festivity [...]. Bells began to ring, and the notes came into the room through the open window, and travelled round Jude's head in a hum. (482)

L'animation et les sons de la rue pénètrent la chambre à demi close du protagoniste. 'agitation est contagieuse, si bien que Jude s'égare peu à peu dans un flot de paroles :

As soon as he could speak he murmured, his eyes still closed: «A little water, please."

Nothing but the deserted room received his appeal, and he coughed to exhaustion again - saying still more feebly : «Water - some water - Sue - Arabella! »

The room remained still as before. Presently he gasped again : «Throat - water Sue - darling - drop of water - please - O please! »

No water came, and the organ notes, faint as a bee's hum, rolled in as before. (483)

50 Ses paroles l'entraînent du versant du symbolique - où le langage est outil de communication et d'échange - vers celui de l'imaginaire - où les mots renvoient la vision et le désir du sujet, même si la soif n'est pas étanchée. Sue demeure l'absente que le souvenir ranime sous les traits du signifiant. Les questions puisées dans le Livre de Job (484) se succèdent bientôt dans la bouche de Jude, mais elles n'attendent aucune réponse, elles ne sont plus des demandes. La voix du protagoniste faiblit, il tousse, cherche son souffle, murmure. Les paroles à peine audibles ne racontent rien d'autre que le désespoir de l'homme qui ne sait ni d'où il vient, ni où il va. Par ses lectures, Jude n'a pas pu faire taire ses interrogations - pas plus que Hardy ne trouva dans le discours de la science l'objet de sa quête.

51 Ainsi, le rapport à la science est à la fois prégnant et problématique chez Hardy. Si l'incipit de la nouvelle The Fiddler of the Reels laisse croire que nous allons en apprendre un peu plus sur la place de la science et du progrès dans l'univers de Hardy, l'espoir du lecteur est bien vite déçu. Passé les deux premiers paragraphes et le commentaire nostalgique du vieux gentleman, c'est une autre histoire d'amours déçues, trompées, volées, d'enfant illégitime et d'amant peu scrupuleux, de tragique ironie de la vie, qui 
nous est contée. La science n'aura été là qu'un point de départ. Elle attire et inspire l'auteur mais s'abîme bientôt sur le rocher du doute; elle se disloque au contact du langage poétique. Cet autre langage, qui naît d'un savoir obscur et ne répond pas à des critères scientifiques, est au cœur de l'écriture de Jude the Obscure. Jude est une figure du poète : il meurt seul, abandonné et incompris. Sa voix, son visage ne quittent cependant pas le texte. Quelque chose se dit à la fin qui rend la tragédie supportable et masque l'horreur. C'est peut-être l'ombre spectrale de Jude. C'est aussi la promesse qu'au-delà de toute vraisemblance ou toute vérification scientifique, la légende poétique à la Tristan et Iseult se répètera dans l'histoire des amants de Thomas Hardy : "She's never found peace since she left his arms, and never will again till she's as he is now! » (Hardy 1996, 490).

\section{BIBLIOGRAPHIE}

Beer, Gillian. Darwin's Plots : Evolutionary Narrative in Darwin, George Eliot, and Nineteenth-Century Fiction. London : Routledge, 1983.

Darwin, Charles. On the Origin of Species by Means of Natural Selection, or the Preservation of Favoured Races in the Struggle for Life. 1859. Harmondsworth : Penguin, 1968.

Hardy, Thomas. The Collected Poems

Collected

of Thomas Hardy. London : Palgrave, Macmillan, 1968.

---. Collected Short Stories. London : Macmillan, 1990.

---. Jude The Obscure. 1895. Harmondsworth : Penguin, 1996.

---. Tess of the D’Urbervilles. 1891. Oxford : Oxford University Press, 1998.

---. The Collected Letters of Thomas Hardy. Ed. Purdy, Richard Little, et al. 1978. Vol. 2. Oxford :

Clarendon Press, 1978-1988.

Kramer, Dale (ed.). The Cambridge Companion to Thomas Hardy. Cambridge : Cambridge University Press, 1999.

Lacan, Jacques. Ecrits. Paris : Seuil, 1966.

Lacan, Jacques. Le Séminaire Livre XX, Encore. Paris : Seuil, 1975.

Lemoine-Luccioni, Eugénie. Le Partage des femmes. Paris : Seuil, 1976.

Weismann, August. Essays Upon Heredity. 1893. June 2009.

<http://www.esp.org/books/weismann/essays/facsimile/.>

Zizeck, Slavoj, et al. (eds.). Gaze and Voice as Love Objects. Durham, NC : Duke University Press, 1996. 


\section{NOTES}

1. «It required an artist to see that the plot is almost geometrically constructed - I ought not to say constructed, for, beyond a certain point, the characters necessitated it, and I simply let it come. » (Letter to Edmund Gosse Nov 10. 1895, in The Collected Letters of Thomas Hardy, vol. 2, p. 93) 2. «L'homme est un, par la grâce du signifiant de son manque, le phallus [...]. Sa jouissance, c'est de trouver dans la femme l'Autre et aussi, tant soit peu, le savoir ou l'avoir. Mais ce savoir ne le divise pas. [...] La femme s'en tient, elle, au manque à être ; l'avoir ou pas restant pour elle du registre de l'imaginaire. » (Lemoine-Luccioni, 200)

\section{RÉSUMÉS}

L'incipit de la nouvelle The Fiddler of the Reels esquisse le point de vue de Thomas Hardy sur la science, suggérant l'opposition entre le passé et le présent, le Wessex et la modernité, la tradition et le progrès. Le contraste dévoile cependant déjà une ambivalence : la faille ( fault ») sépare autant qu'elle crée du lien entre deux mondes. Elle est à la fois séparation et rapprochement ( « an extraordinary chronological frontier or transit-line »). N'est-ce pas là aussi l'un des effets de la nostalgie? Hardy fut clairement attiré par le discours scientifique de son temps dont il fut un lecteur assidu. Mais le regard de l'écrivain n'eut de cesse de réécrire ce discours. Quoique l'emblématique ouvrage de Darwin, The Origin of Species, ait eu une influence considérable sur Tess of the D'Urbervilles et Jude the Obscure, il est indéniable que l'évolutionnisme se trouve pris dans les mailles de l'écriture hardyenne. Ainsi, l'empreinte du Darwinisme ne se perçoit pas à travers un récit naturaliste, mais se donne à lire dans les destins tragiques de personnages dont les existences sont déterminées par les vies de leurs aïeux : les ancêtres déchus de Tess, les tristes parents de Jude. Enfin, Hardy laissa le néo-darwinisme et la notion d'hérédité renouveler sa lecture de la théorie de l'évolution. La généalogie, la transmission familiale, la descendance sont autant d'obsessions qui façonnent les contours de l'univers romanesque et poétique de Hardy.

The opening paragraphs of the short story The Fiddler of the Reels contrast past and present, Wessex and modernity, tradition and progress, revealing Hardy's view of science. His position is ambivalent, as the geological and temporal faultine may be seen as severing, but also connecting, two different kinds of world. As both link and division (« an extraordinary chronological frontier or transit-line »), the faultline is a trope for nostalgia as much as progress. Hardy was clearly attracted to the major scientific texts of his time, and Darwin's emblematic Origin of Species had a considerable influence over Tess of the d'Urbervilles and Jude the Obscure, but there is no denying that scientific discourse is revisioned by the writer's art. Thus the novels which bear the stamp of Darwinism are not naturalistic, biological treatises but tragedies, as the protagonists' fate is determined by the characteristics of previous generations - Tess's fallen ancestors, Jude's weary parents. So that Hardy's reading of life is imbued with a Neo-Darwinian obsession with heredity rather than with evolution per se. Genealogy, family characteristics, filiation are obsessions which shape Hardy's poetic and fictional universe. 
INDEX

Keywords : conformity, desire, fault, heredity, modernity, mutation, selection, university Mots-clés : conformisme, désir, faille, hérédité, modernité, mutation, sélection, université

\section{AUTEURS}

\section{STÉPHANIE BERNARD}

Maître de conférences

Université de Rouen

s.bernard@solidev.org 